\title{
Research of Environmental and Economic Interactions of Coke And By-Product Process
}

\author{
Vladimir Mikhailov ${ }^{*}$, Tamara Kiseleva ${ }^{2}$, Svetlana Bugrova ${ }^{1}$, Alina Muromtseva ${ }^{1}$, and \\ Yana Mikhailova ${ }^{1}$ \\ ${ }^{1}$ T.F. Gorbachev Kuzbass State Technical University, 650000, 28 Vesennyaya St., Kemerovo, Russia \\ ${ }^{2}$ Siberian State Industrial University, 654007, 42 Kirova st., Novokuznetsk, Russia
}

\begin{abstract}
The issues of showing relations between environmental and economic indicators (further - environmental and economic interactions) of coke and by-product process are considered in the article. The purpose of the study is to reveal the regularities of the functioning of the local environmental and economic system on the basis of revealed spectrum of environmental and economic interactions. A simplified scheme of the environmental and economic system "coke and by-product process - the environment" was developed. The forms of the investigated environmental -economic interactions were visualized and the selective interpretation of the tightness of the established connection was made. The main result of the work is modeling system of environmental and economic interactions that allows increasing the efficiency of local ecological and economic system management and optimizing the "interests" of an industrial enterprise - the source of negative impact on the environment. The results of the survey can be recommended to government authorities and industrial enterprises with a wide range of negative impact forms to support the adoption of effective management decisions aimed at sustainable environmental and economic development of the region or individual municipalities.
\end{abstract}

\section{Introduction}

Coke and by-product process is one of the most dangerous sectors of the real economy, which is associated with a wide range of negative effects on all elements of the environment $[1,2]$. An additional problem is caused by the historical territorial location of enterprises near residential areas. Toughening national environmental legislation and international requirements motivate coke production plants to use the innovative modern technologies called BAT (best available technologies). Despite the intensification of this activity, and by-product process is a potential source of high environmental and economic risks, which requires greater efficiency and diversification of management methods used. In such conditions, it is advisable to build a local eco-economic system and its main elements (the enterprise - the source of the negative impact, the control center and the environment). To implement the proposed approach to management, it is necessary to identify the most

*Corresponding author: mvg.eohp@,kuzstu.ru 
significant environmental and economic interactions and to determine the strength of relationship between the correlating variables.

\section{Materials and methods}

The object of the study is Kemerovo Coke and Chemical Enterprise PJSC "Koks". The subject of the study is a system of environmental and economic interactions between Coke and by-product process and the environment. The study is based on an analysis of domestic and foreign literary sources on this issue. Particular attention is paid to studying the dependencies between the basic technical and economic indicators of production and the level of environmental and economic risk, which is of practical importance for the effective management of the local environmental and economic system. The verification of the adequacy of the theoretical developments is based on the confirmation of the factual data of the enterprise taken from the environmental reporting forms. The elements of system analysis and the results obtained by specialists in the management of environmental and economic systems are also used in the work.

\section{Results and discussion}

The integration of the specific eco-economic system, where one of the key places is occupied by the coke and chemical enterprise, requires the analysis of domestic and foreign literature sources, according to which the basic model of the environmental and economic system includes three types of participants [3]:

- management bodies ("center");

- economic agents ("enterprise");

- environment.

The management bodies are "interested" in the effective environmental and economic activity of the managed enterprises, which is expressed in the establishment of environmental and economic requirements for the state of the environment and the use of nature (fines for violation of environmental legislation, provision of credit and tax incentives, etc.). On a qualitative level, the task of the management bodies is to ensure the conditions that motivate enterprises to the most beneficial results for the governing bodies.

The main tasks of the management determine the specifics of environmental and economic systems [3]:

- multivariance of the results of the activities of the managed entities and exposure to a variety of uncontrolled, uncertain and random factors;

- multidirectionality of interests of the management bodies and the enterprises;

- significant costs of the regular receipt of reliable and complete information;

- inability to independently "defend" their interests, including the inertial nature of the reaction;

- crucial importance of institutional constraints (regulatory and legal framework) of enterprises' activities and their interactions with the management bodies.

Fig. 1 presents a simplified scheme of the environmental and economic system "coke and by-product process - the environment". 


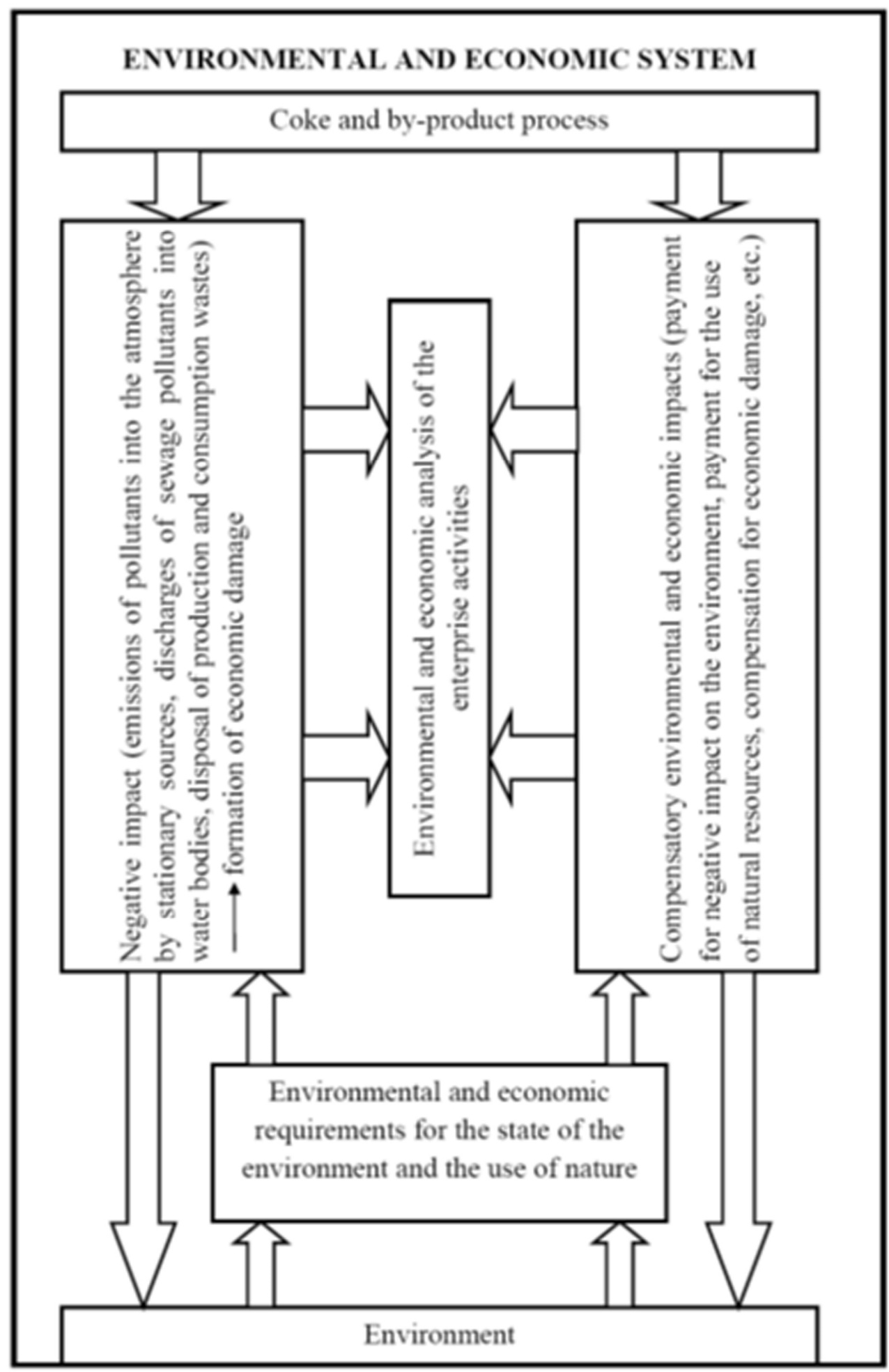

Fig. 1. Simplified scheme of the environmental and economic system "coke and by-product process the environment". 
A number of authors [4] note that the key element in the management of the local ecological and economic system is the nature protection organizational and economic mechanism, the performance of which is assessed by groups of interrelated indicators:

- economic (production volume, profit, cost, technical condition of fixed production assets, level of use of production capacity, etc.);

- environmental indicators, including parameters of negative impact on the environment and other characteristics;

- ecological and economic, characterizing the value of the actual, predicted and damped negative impact on the environment (economic damage, payment for negative environmental impact, fines for violation of environmental legislation, current costs of maintaining environmental fixed assets, etc.).

It is important to clearly structure the organizational and economic mechanism of environmental management consisting of three blocks (analytical, implementation, evaluation of efficiency), which correspond to the following innovative elements [5]:

- reduced integral indicator of the state of the aquatic ecosystem;

- system of enterprises' penalization for providing unreliable information on the level of negative impact on the environment;

- system of universal environmental and economic performance of the enterprise;

- system of environmental and economic indicators of production and consumption wastes;

- diversification of the enterprise's production program according to environmental restrictions.

As a result, a conclusion was made about the maximum belonging of these elements to the analytical block, which additionally reflects its significance.

If we consider the possibility of using these elements to manage the environmental and economic system "coke and by-product process - the environment", then in the conditions of Kemerovo PJSC "Koks" it is possible to use a system of environmental and economic indicators, including those characterizing the movement and efficiency of use of production and consumption waste [ 6].

One of the most important structural elements of the environmental and economic system presented in Fig. 1, are environmental and economic requirements for the state of the environment [7] and the nature use that are generated by public authorities. The implementation of established requirements is carried out through the implementation of environmental measures at various levels, where BAT is at the center [8-10].

The current problem for the conditions of the unstable economy is the financing of nature protection activities. The analysis carried out in allows us to draw the following conclusions:

- financing of nature protection activities in the constituent entities of the country is carried out on a residual basis;

- significant part of sources of nature protection financing is not available to economic entities;

- indirect assistance in the implementation of environmentally oriented management is not practical.

The theoretical analysis of the features of the functioning of environmental and economic systems made it possible to reveal the main environmental and economic interactions presented in Fig. 2. The "+" sign in the cells means high correlation ratio; "-" the weak correlation ratio; empty cells show that the study of the correlation ratio between environmental and economic interactions was not carried out. 


\begin{tabular}{|c|c|c|c|c|c|c|c|}
\hline$x$ & 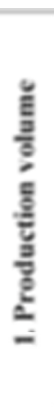 & $\stackrel{\Xi}{\stackrel{2}{2}}$ & 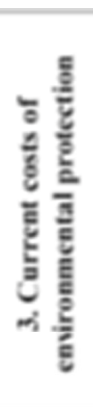 & 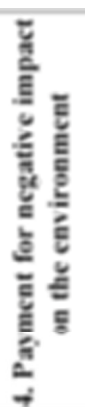 & 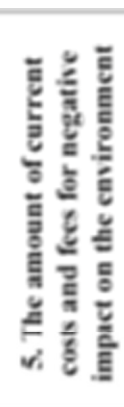 & 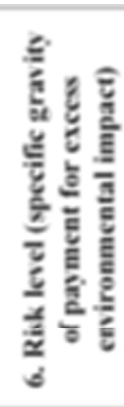 & 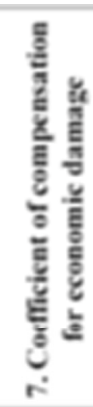 \\
\hline $\begin{array}{l}\text { 1. Production } \\
\text { volume }\end{array}$ & & & & & & & \\
\hline 2. Profit & - & & & & & & \\
\hline $\begin{array}{l}\text { 3. Current costs of } \\
\text { environmental } \\
\text { protection }\end{array}$ & & & & & & & \\
\hline $\begin{array}{l}\text { 4. Payment for } \\
\text { negative impact on } \\
\text { the environment }\end{array}$ & & & - & & & & \\
\hline $\begin{array}{l}\text { 5. The amount of } \\
\text { current costs and } \\
\text { fees for negative } \\
\text { impact on the } \\
\text { environment }\end{array}$ & & & & & & & \\
\hline $\begin{array}{l}\text { 6. Risk level } \\
\text { (specific gravity of } \\
\text { payment for excess } \\
\text { environmental } \\
\text { impact) }\end{array}$ & + & $\cdot$ & + & & + & & \\
\hline $\begin{array}{l}\text { 7. Coefficient of } \\
\text { compensation for } \\
\text { economic damage }\end{array}$ & + & $\cdot$ & + & & + & & \\
\hline
\end{tabular}

Fig. 2. Matrix of connections between the basic environmental and economic interactions of coke and by-product process.

The conducted approximations and correlation analysis of environmental and economic interactions showed a different level of correlation ratio between the variables $\mathrm{x}$ and $\mathrm{y}$. To visualize the result obtained the environmental-economic interactions 1-6 and 3-7, shown in Fig. 3, which have a close statistical dependence and the possibility of their practical management, are chosen. 

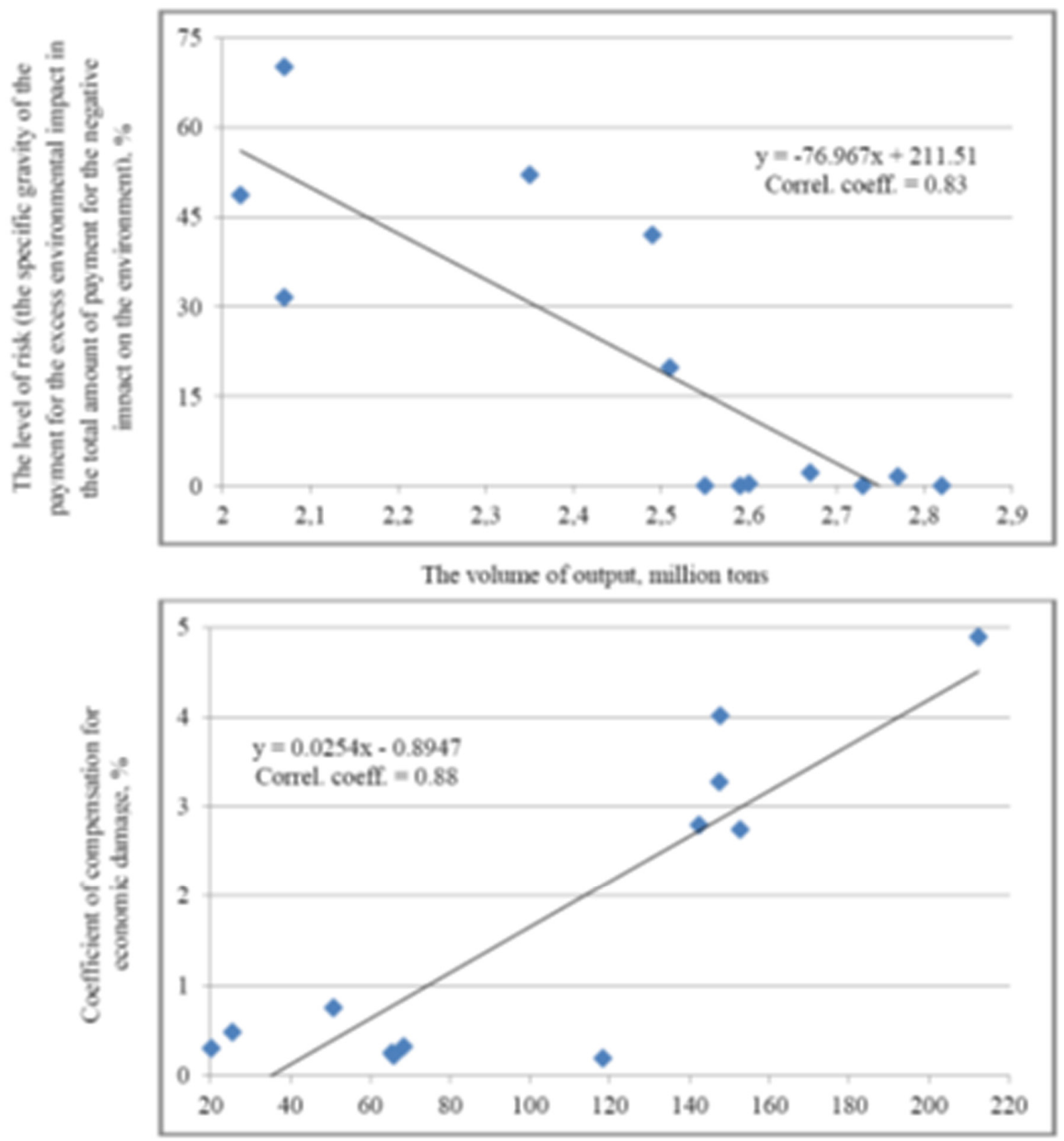

Curreat costs of environmental protection, million rubles

Fig. 3. Correlation fields of the dependencies of some environmental and economic indicators of coke and by-product process.

Environmental-economic interaction 1-6 from Fig. 2, shown in Fig. 3 is satisfactorily described by the linear dependence and reflects the decrease in the level of risk with increasing output, for example, in the range from 2.55 to 2.82 million tons of coke, the level of risk is zero, and when a production volume is of 2.07 million tons, the level of the risk is $70.13 \%$. Environmental-economic interaction 3-7 is most adequately described by a linear dependence. As a result, the growth of current costs and fees for negative impact leads to an increase in the economic damage compensation ratio. The maximum value of the economic damage compensation coefficient $(4.9 \%)$ is observed with the current environmental expenditures amounting to 212.4 million rubles.

\section{Conclusions}


The conducted research of environmental and economic interactions of coke and byproduct process allowed drawing the following conclusions:

- the main environmental and economic indicators, between which an attempt was made to establish statistical links, were identified;

- an analysis of various theoretical approaches to the construction and interpretation of environmental and economic systems was carried out;

- a simplified scheme of the environmental and economic system " coke and by-product process - the environment" was built;

- a matrix of connections between the basic environmental and economic interactions of coke and by-product process was developed;

- a correlation analysis of the dependencies between the most significant indicators of the environmental and economic system was made establishing the correlation ratio between them;

- linear dependencies between the volume of output and the level of risk, as well as between the amount of current costs for environmental protection and the compensation coefficient of economic damage with a high degree of relationship are revealed, which allows managing these indicators to stabilize the state of the environmental and economic system.

\section{References}

1. S. V. Gerasimov, N. G. Kolmakov, Coke and Chemistry, 58:5, 184 (2015)

2. V. N. Burkov, I. V. Burkova, Game Theory and Application. 17, 17 (2015)

3. T. V. Kiseleva, V. G. Mikhailov, V. A. Karasev IOP Conf. Series: Earth and Environmental Science, 45, 012013 (2016)

4. V. G. Mikhailov, T. V. Kiseleva, V. A. Karasev, G. S. Mikhailov, V. A. Skukin, IOP Conf. Series: Earth and Environmental Science, 66, 012008 (2017)

5. V. G. Mikhailov, N. N. Golofastova, T. V. Galanina, T. G. Koroleva, Ja. S. Mikhailova, IOP Conf. Series: Earth and Environmental Science, 50, 012038 (2017)

6. S. N. Dyakov, A. V. Papin, A. V. Nevedrov, E. V. Zhbyr, Coke and Chemistry, 55:10, 363 (2012)

7. H. P. Tiwari, R. Sharma, R. Kumar, P. Mishra, A. Roy, S. K. Haldar, Coke and Chemistry, 57:12, 477 (2014)

8. S. Kordana, E3S Web Conf., 17, 00042 (2017)

9. N. N. Yashalova, D. A. Ruban, Economic and Social Changes: Facts, Trends, Forecast, 47:5, 219 (2016)

10. A. Pimonov, E. Raevskaya, T. Sarapulova, E3S Web Conf., 15, 01021 (2017) 
